\title{
INTERFERENSI BAHASA INDONESIA TERHADAP PENGGUNAAN ADPOSISI BAHASA JEPANG PADA BAHASA TULIS

\author{
(Studi Kasus terhadap Mahasiswa Angkatan 2010 Sastra Jepang Universitas \\ Brawijaya, Malang)
}

\author{
Febi Ariani Saragih \\ Universitas Brawijaya Malang \\ Email: emiwk74@yahooco.jp
}

\begin{abstract}
Abstrak: Tujuan penelitian ini adalah untuk mengetahui (1) bagaimana kesalahan interferensi B1 dalam penggunaan adposisi bahasa Jepang, (2) bagaimana interferensi hubungan gramatikal dalam penggunaan adposisi bahasa Jepang yang muncul pada bahasa tulis, dan (3) bagaimana tingkat kesulitan adposisi bahasa Jepang berdasarkan interferensi yang muncul pada bahasa tulis mahasiswa angkatan 2010 sastra Jepang Universitas Brawijaya, Malang. Metode yang digunakan dalam penelitian ini adalah kuantitatif dan kualitatif. Metode kuantitatif digunakan untuk mencari validitas dan realibilitas test, serta mencari frekuensi terbanyak dari kesalahan yang dibuat siswa. Sumber data penelitian ini adalah siswa, sedangkan data diperoleh dari hasil tes yang dikerjakan siswa, serta hasil interview. Hasil yang diperoleh bahwa interferensi bahasa Indonesia pada penggunaan adposisi bahasa Jepang dalam kalimat yang dibuat siswa terjadi pada adposisi wa, mo, ga, o, ni, de, dan no. Interferensi hubungan gramatikal yang terjadi pada penggunaan adposisi bahasa Jepang dalam bahasa tulis yang dibuat siswa adalah transfer hubungan gramatikal B1 melanggar pola hubungan gramatikal B2, tetapi maknanya masih bisa dimengerti secara tersirat. Adposisi yang termasuk dalam transfer hubungan gramatikal B1 melanggar hubungan gramatikal B2 ini adalah $n i, e, d e, o$, dan no. Tingkat kesulitan adposisi bahasa Jepang berdasarkan interferensi yang muncul pada bahasa tulis mahasiswa sastra Jepang angkatan 2010 Universitas Brawijaya Malang adalah taiou /transfer (1-1) $\rightarrow$ dounyuu/overdifferensiasi $(0-1) \rightarrow$ tougou /konvergensi (2-1).
\end{abstract}

Kata Kunci : interferensi, makna, gramatikal

Abstract: The research is aimed at describing (1) how is the mistake of Bahasa Indonesia (B1)'s intereference in adpositional use in Japanese (2) how is the grammatical relation interference in adpositional use of Japanese (B2), (3) how is the level of difficulty of Japanese adpositional found in students of 2010 Japanese Literature Brawijaya University's written expression. The method of the research is quantitative and qualitative. Quantitative method is used to validate and to find the reliability of the test. On the other hand, it is also used to find the most frequent mistakes made by students. The research's source is the students, while the data are taken from the students' tests and interviews. The analysis shows that B1's interference on the use of B2's adpositionals in sentences are found in adpositionals wa, mo, ga, o, ni, de, and no. Grammatical relation intereferences in B2's adpositional in written expression are considered as grammatical relation transfer of $B 1$ which deviates the pattern of grammatical relation of B2. However, the meaning of the sentences are still 
understandable implicitely. Some adpositions considered in B1's grammatical relation transfer are $n i, e, d e, o$, and no. The level of difficulty of B2 based on its intereference on the students' written expression of 2010 Japanese Literature students of Brawijaya University of Malang are taiou /transfer (1-1) $\rightarrow$ dounyuu/overdifferensiasi(0-1) $\rightarrow$ tougou /konvergensi (21).

Keywords: interference, meaning, grammatical

\section{Pendahuluan}

Kesalahan selalu terjadi ketika memperlajari suatu bahasa. Salah satu penyebab kesalahan tersebut adalah karena kesulitan yang dialami pembelajar. Dalam pembelajaran bahasa asing, salah satu penyebab kesulitian itu adalah adanya interferensi bahasa ibu. Pembelajaran bahasa Jepang di Indonesia biasanya dimulai pada tingkat Sekolah Menengah Atas dan Perguruan Tinggi. Jadi bisa dikatakan bahwa siswa sudah dalam usia dewasa. Karena sudah dewasa, tentunya dalam diri siswa sudah melekat sistem gramatika B1 mereka. Hal ini sesuai dengan yang dikemukan oleh Setyawati (2010:10) yang membagi faktor penyebab seseorang salah dalam berbahasa menjadi tiga yaitu: 1 . Terpengaruh bahasa yang lebih dahulu dikuasainya. Ini dapat berarti bahwa kesalahan berbahasa disebabkan oleh interferensi bahasa ibu terhadap bahasa kedua yang sedang dipelajari si pembelajar (siswa). 2. Kekurangpahaman pemakai bahasa terhadap bahasa yang dipakainya. Jika siswa kurang paham terhadap bahasa yang dipelajari, maka siswa cenderung meraba-raba maupun membuat generelalisasi terhadap materi yang dipelajari, dan 3. Pengajaran bahasa yang kurang tepat atau kurang sempurna. Hal ini mengakibatkan pembelajar salah persepsi maupun tidak begitu mengerti apa yang diterangkan oleh pengajar.

Dalam pembelajaran bahasa Jepang tingkat dasar, dikenal adposisi yaitu $w a, g a$, mo, o, to, ni, mo, de, ya, dake/shika, kara, made, no. Peneliti sebagai pengajar bahasa
Jepang, sering menemukan kesalahan yang dilakukan oleh pembelajar bahasa Jepang dalam penggunaan adposisi ketika membuat kalimat maupun ketika mengerjakan test (mengisi adposisi pada kalimat). Sering ditemukan bahwa pembelajar mengisi adposisi sesuai dengan makna adposisi tersebut dalam bahasa Indonesia. Misalnya dalam kalimat berikut ini,

(1)Doubutsuen ni tora ga imasu

Kebun

binatang/adposisi/hariamau/adpsosi/ada

Ada harimau di kebun binatang

Pada penyusunan kalimat di atas, ada pembelajar yang mengisi adposisi $n i$ dengan adposisi de. Adposisi $n i$ dan de mempunyai peran semantik yang sama yaitu menyatakan tempat tetapi dalam konteks yang berbeda. Namun dalam bahasa Indonesia, baik adposisi ni maupun de mempunyai makna sama dalam konteks kalimat di atas, yaitu di. Sehingga pembelajar cenderung memilih de karena mirip dengan preposisi bahasa Indonesia $d i$.

Sehubungan kesalahan yang terjadi pada kalimat di atas, maka analisis kesalahan penting dilakukan seorang pengajar karena bermanfaat dalam 1.Menentukan urutan penyajian butir-butir yang diajarkan dalam kelas dan buku teks, misalnya urutan mudah-sukar. 2. Menentukan jenjang relatif penekanan, penjelasan, dan latihan berbagai butir bahan yang diajarkan. 3. Merencanakan latihan dan pengajaran remedial, dan 4. Memilih butir-butir bagi pengujian kemahiran siswa. Dari hasil analisis butir-butir yang sukar dan mudah, pengajar dapat lebih 
mempertimbangkan butir-butir yang akan dikeluarkan sebagai soal, sehingga persentase soal sukar dan mudah akan seimbang. Tarigan (1988:69).

Kesalahan yang disebabkan interferensi B1 menuntut seorang pengajar untuk mengembalikan permasalahan kepada B1 siswa.Untuk itu dalam menganalisis, diperlukan juga analisis kontrastif (anakon).Analisis kontrastif adalah aktivitas atau kegiatan yang mencoba membandingkan struktur B1 dengan struktur B2 untuk mengidentifikasi perbedaan-perbedaan di antara ke dua bahasa (Tarigan, 1988:23).Kontras adalah sesuatu yang bertolak belakang, sehingga analisis ini mencari struktur-struktur yang bertolak belakang saja.Analisis ini dapat digunakan sebagai landasan dalam meramalkan atau memprediksi kesulitankesulitan berlajar bahasa yang dihadapi siswa, terutama B2.

Pronomina adalah kata yang dipakai untuk mengacu ke nomina lain. Pronomina dalam bahasa Indonesia dibagi menjadi tiga yaitu :pronomina persona (saya, engkau dia), pronomomina penunjuk (ini, itu, sini, sana, begini, begitu), pronominapenanya (siapa, apa, mana). Dari ketiga jenis pronomina di atas, adposisi bahasa Jepang dapat disetarakan dengan pronomina persona orang ketiga seperti yang ditunjukkan dalam contoh zoo wa hana ga nagai (gajah belalainya panjang), serta pronomina penanya seperti dalam contoh dare ga kono okashi o tabemashita $k a$ (Siapa yangtelah makan kue ini?) dimana partikel ga berfungsi sebagai pemarkah kata tanya.

Dalam sebuah kalimat bahasa Jepang biasanya terdiri dari topik (shudai), subjek (shugo), objek (mokutekigo), dan predikat (jutsugo). Dan dalam sebuah kalimat sederhana bahasa Jepang, sekurang kurangnya menggunakan tiga kata. Misalnya kalimat watashi wa taberu (saya makan), menggunakan nomina, adposisi, dan verba.Dari kelimat tersebut dapat diketahui bahwa dalam kalimat yang paling sederhana pun, menuntut kehadiran adposisi.Adposisi adalah salah satu faktor yang membentuk struktur kalimat dalam sistem gramatika bahasa Jepang. Ishikawa (2006) menyatakan:

$$
\begin{aligned}
& \text { 助詞というのは、付属語 } \\
& \text { （非立語）であって、活 } \\
& \text { 用しないものであり、ま } \\
& \text { た、格助詞というのは、 } \\
& \text { 述語との関係を表す助詞 } \\
& \text { である。格助詞は動詞だ } \\
& \text { けでなく、形容詞や名詞 } \\
& \text { との関係も表す }
\end{aligned}
$$

Artinya:

Yang disebut dengan Joshi adalah kata yang tidak berdiri sendiri yang tidak mengalami perubahan. Sedangkan kaku joshi adalah joshi yang menyatakan hubungan dengan predikat.Kaku joshi tidak hanya menyatakan hubungan dengan verba saja, tetapi juga mendeskripsikan hubungan kata sifat dan kata benda).

Karena joshi merupakan kata tugas, maka dengan sendirinya tidak bisa berdiri sendiri. Dia harus diikuti oleh kata lainnya. Sama dengan halnya adposisi bahasa Indonesia, misalnya $k e$, tentunya tidak bisa berdiri sendiri. Dia menuntut kehadiran kata tempat. Sedangkan kaku joshi yang merupakan salah satu jenis adposisi, berfungsi sebagai penghubung predikat, yang menghubungkan verba, adjectiva dan noun. Misalnya kaku joshiga, dalam watashi ga tabeta (saya makan). Ga adalah penanda predikat pada kata tabeta (makan), dan menghubungkan verba tabeta (makan). 
Karakteristik sebuah joshi (adposisi) adalah sebagai salah satu jenis fuzokugo (kata yang tidak bisa berdiri sendiri) yang selalu menempel pada jiritsugo (kata penuh/berdiri sendiri) dalam sebuah bunsetsu (klausa); atau merupakan tango (morfem) yang tidak mengalami katsuyoo (infleksi); dan fungsinya adalah untuk menunjukkan hubungan antar goku (katakata dan frase-frase), seperti hubungan antara shugo (subyek) dengan shushokugo (modifikator) (Kentaro Aoki (1997: 66-72). Dikatakan sebagai kata yang tidak berdiri sendiri, karena adposisi selalu mengubungkan kata yang ada di depan maupun di belakangnya. Selalu menempel pada kata penuh berarti adposisi tidak bisa menempel pada kata yang tidak bisa berdiri sendiri. Dan adposisi itu akan membentuk sebuah klausa, misalnya haha wa suupa e ikimasu (ibu pergi ke pasar). Adposisi merupakan morfem, sehingga dia juga mempunyai makna. Dalam hal ini yaitu makna gramatikal. Jadi adposisi e pada contoh kalimat di atas bermakna $k e$. Adposisi wa menunjukkan hubungan subjek, adposisi $e$ menunjukkan hubungan antara predikat dan keterangan.

Dari definisi diatas diketahui bahwa baik adposisi bahasa Jepang maupun adposisi bahasa Indonesia (dalam hal ini preposisi) sama-sama merupakan kata tugas atau kata yang tidak berdiri sendiri, tetapi adposisi bisa menghubungkan kata sifat dan kata benda, sedangkan preposisi bahasa Indonesia tidak menghubungkan kata sifat dan kata benda. Dalam bahasa Indonesia fungsi tersebut dilakukan oleh konjungsi.

Seluruh adposisi bahasa Jepang merupakan faktor penyusun dalam pembentukan sistem gramatika bahasa Jepang. Umehara yang dikutip oleh Hando (2005:141) mengatakan bahwa setiap adposisi mempunyai makna sendiri-sendiri, dan menempel dengan konstituen di depannya yang merupakan kata yang mempunyai fungsi struktur hubungan. Dengan kata lain adposisi sebagai penghubung dalam pembentukan kalimat. Makna adposisi akan berbeda-beda tergantung pada konstituen yang menempel. Misalnya dalam kalimat watashi wa imouto ni ame o agemasu (Saya memberi permen kepada adik), adposisi $n i$ bermakna kepada. Sedangkan dalam kalimat watashi wa haha ni okane o moraimashita (saya menerima uang dari ibu) adposisi $n i$ bermakna dari.

Secara umum, adposisi bahasa Jepang mempunyai hubungan pada struktur bentuk kalimat dan mempunyai hubungan dengan makna (informasi yang disampaikan), atau mempunyai hubungan dengan keduaduanya (bentuk kalimat dan makna). Jika dalam hubungan struktur bentuk kalimat adposisi tidak digunakan maka akan menjadi kalimat yang tidak berterima. Jika dalam hubungan makna adposisi tidak digunakan, maka informasi yang disampaikan oleh kalimat itu akan berbeda,dan akan menjadi kalimat dengan makna yang lain. Misal dalam kalimat: (1) watashi tomodachi Jakarta ikimasu(saya teman Jakarta pergi), dan (2) tomodachi kikimasu (teman bertanya). Kalimat (2) tidak berterima karena tidak jelas siapa yang pergi ke Jakarta. Kalimat (1) bermakna saya dan teman pergi ke Jakarta jika menggunakan adposisi to, sedangkan akan bermakna teman saya yang pergi ke Jakarta, jika menggunakan adposisi no.Kalimat (2) ini maknanya juga membingungkan. Apakah bermakna tomodachi ga kikimasu (teman bertanya), atau tomodachi ni kikimasu (bertanya kepada teman).

Kasus tidak digunakannya adposisi dalam bahasa Jepang disebut mujoshi. Dalam bahasa tulis kasus mujoshi tidak ditemukan, tetapi dalam bahasa lisan sering ditemukan. Mujoshi sering ditemukan dalam frasa nomina. Misalnya: (4) watashi $\varnothing$ ashita no paatii ni iku (Saya besok pergi ke pesta).(5) Toukyou Ø itta toki, kutsu $\varnothing$ 
katte kite ne(Kalau pergi ke Tokyou beli sepatu ya).Jika bukan sebagai topik, tidak semua adposisi kasus bisa hilangkan. Adposisi kasus yang bisa dihilangkan adalah $g a, o, n i$ (menyatakan arah), dan $e$. Sedangkan yang tidak bisa dihilangkan adalah $n i$ (benefit), de, to, kara, made.

Seperti halnya pembagian kelas kata, pembagian atau klasifikasi adposisi dalam bahasa Jepang pun berbeda-beda menurut pendapat para linguis sesuai dengan teori yang mereka gunakan. Namun secara garis besar adpsoisi bisa dibagi menjadi dua, yaitu toritate joshi/adposisi yang menunjukkan topik (wa, mo, dake, shika) dan kaku joshi (ga, o, ni , de, kara), (Ichikawa,1997). Kaku joshi diturunkan lagi menjadi rentai joshi/ adposisi penyambung no dan fukugo joshi (toshite, ni totte, ni taishite, ni kanshite). Dapat kita lihat bahwa toritate joshi sama dengan kakari joshi. Tetapi fuku joshi (dake, shika) masuk juga dalam toritate joshi.

Kaku joshi (格助詞-adposisi kasus) adalah adposisi yang membawa hubungan pada pembentukan kalimat sebagai faktor penyusun kalimat, juga berfungsi untuk menunjukkan hubungan makna yang ada di antara taigen dan yougen, tetapi tidak menimbulkan hubungan selain dari itu. (Hando,2005:136). Rentai joshi (連体助詞) adalah adposisi yang berfungsi untuk membuat hubungan secara sintaksis diantara sesama taigen(Hando,2005:133). Rentai joshi yang paling umum adalah partikel no yang berfungsi memodifikasi rentai. Misalnya dalam kalimat sakura no sono (kebun sakura), watashi no kare (lakilaki saya). Meskipun no mengekspresikan berbagai macam hubungan,tetapi tidak ada batasan no tersebut hanya mengekspresikan hubungan yang bagaimana. No yang terletak di depan dan di belakang taigen, tidak mengekspresikan hubungan makna bagaimana pada kedua taigen tersebut. Maknanya diserahkan pada penerimaan lawan bicara. Untuk itu diperbolehkannya menafsirkan berbagai macam makna no pada ekspresi yang dihubungkan oleh adposisi no adalah karena alasan tersebut. Misalnya: sakura no hana (kebun yang penuh dengan sakura); watashi no kare (laki-laki yang saya sukai); watashi no hon (buku punya saya); haru no ensoku ( piknik yang diadakan di musim semi).

Kakari joshi (係り助詞) adalah kategori adposisi yang mempunyai fungsi gramatika oritate. Fungsi toritate pada kakari joshi adalah mengkhususkan secara struktur dan secara makna dua hal yang ada di depan dan di belakang kakari joshi. Dengan pola tersebut ada dua toritate yaitu toritate yang pasti dan toritate yang memiliki batasan. Tetapi jika dilihat dari perbedaan struktur masing-masing kalimat, maka akan timbul penggunaan/fungsi sebagai topik dan fungsi sebagai perbandingan. Misal, (6) Watashi wa Yamada desu(saya Yamada), (7))Yasai mo taberu (sayur juga makan). Wa dalam kalimat (6) merupakan toritate yang pasti yang berfungsi membentuk hubungan secara sintaksis pada hubungan yang disebut dengan topik-penjelasan. Sedangkan mo dalam kalimat (7) selain membentuk hubungan secara sintaksis berdasarkan fungsi topik, juga membentuk hubungan hanretsu (paradigmatic). Jadi bisa disimpulkan bahwa kakari joshi selain berfungsi umum menghubungkan secara sintaksis, juga mengemban fungsi untuk membentuk hubungan hanretsu. Toritate joshi bisa juga digunakan bersama-sama dengan kaku joshi. Misal :(8) a.Nihon ni kisetsu ga yotsu arimau ( Ada 4 musin di Jepang), b.Nihon ni wa kisetsu ga yotsu arimasu. Kalimat (8)a merupakan kalimat kenyataan secara obyektif (kyakkan teki na jijitsu) . Sedangan (8)b. Adalah salah satu bagian dari keyataan secara obyektif tersebut diambil dijadikan topik (Iori, 2004:315) 
Heiritsu joshi（並立助詞） juga merupakan adposisi yang menghubungakan sesama taigen. Yang termasuk heiritsu joshi adalah to, toka, ya, yara, nari, dan lain-lain. Ada yang menggunakan model $\sim$ to , ada juga yang menggunakan model $\sim$ to $\sim$ to . Misalnya, (9)watashi wa ringo to mikan ga suki (saya suka apel dan jeruk), (10)kaban no naka ni hon toenpitsu tosaifu ga aru (di dalam tas ada buku, pensil, dan dompet). Sebagaian besar heiritsu joshi yang ada di belakang disingkat, dan heiritsu yang ada di belakang tersebut ada/tidak, tidak berpengaruh banyak terhadap makna (Yoshii, 1989).Hando sendiri menganggap bahwa heiritsu joshi yang ada di depan penggunaannya tinggi dan mempunyai fungsi seperti rentai joshi, sedangkan heiritsu joshi yang ada di belakang hanya ekspresi formalitas dan bisa dikatakan idiomatik. Sehingga contoh pada kalimat (9) penggunaan adposisito adalah wajib, sedangkan pada contoh kalimat(10) to di belakang bisa disingkat.

Dalam pembelajaran bahasa Jepang, biasanya siswa tidak mengenal pembagian jenis adposisi. Siswa hanya tahu bahwa adposisi adalah joshi yang biasanya ditandai dengan penggunaan satu atau dua huruf hiragana (dua huruf untuk partikel kara dan made). Untuk itu, dalam penelitian kali ini tidak mengkhususkan pembagian adpsisi menurut jenisnya, tapi langsung mengambil adposisi yang biasanya dipelajari siswa dalam buku Minna no Nihongo, dalam hal ini yang menjadi obyek penelitian adalah kaku joshi,toritate joshi/kakari joshi, rentai joshi, dan heiritsu joshi. Berikut ini akan dijelaskan masingmasing peran semantikdan sintaksis dari adposisi bahasa Jepang.

Adposisi wa mempunyai peran sebagai semantik yang menunjukkan topik, perbandingan/kontras, dan penekanan/ penegasan. Adposisi mo mempunyai peran semantik menunjukkan kesamaan suatu hal/benda, penekanan, menambah nilai rasa, perkiraan suatu contoh, negasi.Peran sintaksis dari adposisi ga adalah menyatakan subjek, objek (hubungan dengan predikat), dan sebagai penanda modifikator, keberadaan, kata bantu verba intransitif. Adposisi $o$ mempunyai fungsi gramatika sebagai object dari suatu kegiatan, serta mempunyai peran semantik tempat tempat aktifitas, tempat dilaluinya suatu proses atau kegiatan, titik awal terjadinya suatu aktivitas (untuk verba intransitif).Adposisi $n i$ mempunyai peran semantik menyatakan tempat keberadaan, waktu, titik sampai, benefit/penerima, sebab/alasan, tujuan, frekuensi, arah, taraf keadaan, hubungan dengan sesuatu, bagian mana kita melakukan sesuatu, pelaku/dari mana suatu hal didapat, hasil.Adposiside mempunyai peran semantik menyatakan tempat dilakukannya aktivitas, cara, alat, bahan, kisaran, batas, alasan, waktu. Adposisie mempunyai peran semantik menyatakan arah suatu aktivitas, dan pasangan. Adposisito mempunyai makna dan fungsi untuk menyatakan pasangan aktifitas, kutipan, menunjukan lebih dari satu, menunjukkan nama, sesuatu yang dipikirkan. Adposisikara mempunyai peran semantik menyatakan titik awal, menerima sesuatu dari lawan bicara, sebab, dasar penilaian, dan bahan.Adposisino mempunyai peran semantik menyatakan milik, hubungan pelaku, sifat dari kata benda yang mengikutinya, membentuk modifikator, penghubung tempat. Adposisi made mempunyai peran semantik menyatakan batasan suatu hal, waktu dan tempat. Adposisi ya mempunyai peran semantik menyebutan sebagian dari benda sebagai

Karena perbedaan peran semantic pada adposisi bahasa Indonesia dan bahasa Jepang tersebut akhirnya menimbulkan interferensi dalam penggunaan adposisi bahasa Jepang. Interferensi adalah ikut campurnya sistem bahasa B1 dalam sistem bahasa B2.Weinreich (Ibid: 14-61) sendiri 
membagi interferensi hubungan gramatikal menjadi tiga yaitu :1. Transfer hubungan gramatikal B1 membawa makna yang tidak sesuai pada B2.Pengidentifikasi dari B1 secara eksplisit dan tidak sengaja akan mengandung makna yang berbeda dari makna yang dimaksud. Misalnya dalam kalimat Nihon no daigaku de benkyou shite iru (Belajar di universitas yang ada di Jepang), oleh pembelajar diidentifikasi menjadi Nihon daigaku de benkyou shite iru (Belajar di Universitas Nihon). Ke dua kalimat ini memiliki makna yan berbeda. Kalimat pertama menyatakan orang yang belajar di salah satu universitas yang ada di Jepang, sedangkan kalimat ke dua (yang dibuat siswa) mengandung makna orang yang belajar di universitas yang bernama Nihon.2. Transfer hubungan gramatikal B1 melanggar pola hubungan gramatikal B2.Transefer hubungan ini melanggar pola, namun masih bisa dimengerti secara tersirat. Misal seorang pembelajar yang ingin membuat kalimat "terlambat ke sekolah" dalam bahasa Jepang menjadi gakkou $e$ chikoku shita, (yang benar adalah gakkou ni chikoku shita). 3. Transfer hubungan gramatikal B1 menimbulkan hubungan gramatikal yang tidak wajib pada B2. Misal, "saya tidak bisa tidur di malam hari" dalam bahasa Jepang watashi wa yoru ninemuremasen. Sedangkan yang benar adalah watashi wa yoru nemuremasen.

Dalam hal pembelajaran bahasa Jepang ini, faktor yang memungkinkan terjadinya interferensi adalah: 1.Kedwibahasaan pembelajar:Pembelajar dari Indonesia, rata-rata adalah seorang dwibahasawan. 2. Perbedaan antara bahasa sumber dan bahasa sasaran: Sedikit sekali persamaan antara bahasa Indonesia dan bahasa Jepang, terdapat bagian yang mencolok yang menyebabkan kesulitan, serta tidak cukupnya kata-kata bahasa penerima. 3. Ada siswa yang mudah dipengaruhi B1: Ini berkaitan dengan tipisnya kesetiaan terhadap B2, sehingga siswa mudah dipengaruhi B1 atau terbawanya kebiasaan dalam B1. 4. Kemampuan berbahasa: Siswa memendam ketidakmengertian terhadap bahasa sasaran, sehingga ragu-ragu dalam menggunakan /memilih kata-kata.

Dari kegiatan analisis kontrastif di atas, dapat diketahui tingkat kesulitan yang dialami olah siswa. Sehubungan dengan tingkat kesulitan ini, Lifford Prator (1967) membagi hiererki kesulitan menjadi enam tingkatan. Ia mengambil contoh perbandingan bahasa Inggris dan Spanyol (Brown, 2007:274). Hierarki Prator adalah sebagai berikut:

1) Tingkat 0-Transfer: tidak ada perbedaan atau kontras antara ke dua bahasa. Pembelajar bisa begitu saja mentrasfer secara positif sebuah bunyi, struktur, atau item leksikal dari bahasa asal ke bahasa sasaran. Misal : pergi ke sekolah dalam bahasa Jepang gakkou e iku.

2) Tingkat 1-Perpaduan: Dua item dalam B1 berpadu menjadi satu item dalam B2. Ini mengharuskan pembelajar mengabaikan sebuah pembeda yang sudah mereka akrabi.

3) Tingkat 2-Subdiferensiasi: Sebuah item dalam B1 tidak ada dalam B2. Pembelajar harus menghindari item tersebut.

4) Tingkat 3-Reinterpretasi : Sebuah item yang ada pada B1 diberi bentuk atau distribusi baru.

5) Tingkat 4-Overdiferensiasi: Sebuah item yang sepenuhnya baru yang harus dipelajari, kalaupun mirip hanya sedikit dengan item bahasa B1. Misal; makanØ nasi dalam bahasa Jepang adalah gohan o tabemasu.

6) Tingkat 5-Pembelahan: Satu item dalam B1 menjadi dua atau lebih dalam B2, yang memuntut pembelajar membuat sebuah pembeda baru. Misal: "makan di kantin", terbang di udara, dalam bahasa Jepang shokudo de taberu, sora o tobu. 
Penelitian mengenai adposisi telah banyak dilakukan, misalnya: Mizutani Nobuko (1987) meneliti tentang kesulitan memahami perbedaan adposisi $n i$ dan $d e, o$ dan $g a$ oleh pembelajar yang ber B1 bahasa Inggris. Hasil penelitiannya adalah untuk semua tempat aktivitas, hampir tidak ada pembelajar yang memilih adposisi de. Hal ini dikarenakan pembelajar membandingkannya dengan verb be dalam bahasa Inggris. Tetapi untuk verba sumu (tinggal),tsutomeru (bekerja), dan atsumaru (berkumpul), karena dalam bahasa Inggris setara dengan live, work for, together maka pembelajar menggunakan adposisi de. Kubota Miko (1994) melakukan penelitian kesalahan penggunaan adposisi, studi kasus terhadap 2 orang pembelajar bahasa Jepang yang ber B1 bahasa Inggris. Hasil penelitiannya adalah banyak terdapat kesalahan dalam penggunaan adposisi $e$ yang menyatakan arah, nidande yang menyatakan tempat. Untuk nidande diketahui pembelajar lebih sering menggunakan adposisi $n i$ dari pada de. Hal ini berlawanan dengan hasil penelitian Matsuda dan Saito (1992), yang menyatakan bahwa pembelajar yang ber B1 bahasa Korea, lebih sering menggunakan adposisi de daripada ni.Kamimura Fumiko dan Hasui Masako (2002) meneliti tentang tingkat kesulitan kaku joshi, terhadap 33 siswa dari 9 negara yang datang ke Jepang. Metode penelitian dengan cara angket mengisi adposisi (ana ume tesuto). Hasilnya diketahui ada 24 orang yang melakukan kesalahan untuk adposisi $n i$, 19 orang untuk adposisi ga, 15 orang untuk adposisi de, 9 orang untuk adposisi $o, 4$ orang untuk adposisi $e$, serta 3 orang untuk adposisi to. Alasan yang dikemukakan siswa mengapa adposisi $n i$ paling sulit salah satunya adalah karena fungsi penggunaannya lebih banyak dibandingkan adposisi ga dan $o$. Shibuya (2001) meneliti tentang tingkat kesulitan pembelajaran bahasa Jepang dalam kaitannya dengan interferensi bahasa ibu terhadap pembelajar yang ber B1 bahasa Inggris. Hasil penelitian Shibuya terangkum dalam tabel berikut ini.

Tabel 1.1 Tingkat Kesulitan Bahasa Jepang pada Siswa ber B1.Bahasa Inggris

$\begin{array}{llccl}\begin{array}{c}\text { Tingkat } \\ \text { Kesulitan }\end{array} & \text { Keterkaitan } & \begin{array}{c}\text { Bahasa } \\ \text { Ibu } \\ \text { (Inggris) }\end{array} & \begin{array}{c}\text { Bahasa Target } \\ \text { (Jepang) }\end{array} & \begin{array}{c}\text { Contoh } \\ \text { (Bahasa } \\ \text { Jepang) }\end{array} \\ \text { sulit } & \text { (A) Bunka } & 1 & 2 & \text { Aru dan iru } \\ & \text { (B) Dounyuu } & 0 & 1 & \text { wa } \\ & \text { (C) Sakujo } & 1 & 0 & \text { plural } \\ & \text { (D) Tougou } & 2 & 1 & \sim \text { te iru } \\ \text { mudah } & \text { (E) Taiou } & 1 & 1 & \text { Past tense }\end{array}$

1. Bunka : Jika bahasa Inggris mempunyai 1, bahasa Jepang mempunyai 2

2. Dounyuu: Jika bahasa Inggris tidak punya dan bahasa Jepang punya

3. Sakujo: Jika Bahasa Inggris punya, dan bahasa Jepang tidak punya

4. Tougou: Bahasa Inggris punya dua model sedangkan bahasa Jepang hanya punya satu

5. Taiou: Bahasa Inggris dan bahasa Jepang sama-sama mempunyai

Meskipun sudah banyak penelitian tentang adposisi bahasa Jepang, namun penelitian ini masih mungkin dilakukan karena ada perbedaan dengan penelitan sebelumnya. Pada penelitian sebelumnya tidak melihat kesulitan dari factor 
interferensi bahasa ibu, dan dalam penelitian Shibuya membandingkan semua aspek gramatikal.Sedangkan pada penelitian ini hanya membandingkan adposisi saja. Untuk itu pada penelitian bertujuan untuk mengetahui: 1. Bagaimana kesalahan interferensi B1 dalam penggunaan adposisi bahasa Jepang, 2 . Bagaimana interferensi hubungan gramatikal dalam penggunaan adposisi bahasa Jepang yang muncul pada bahasa tulis, dan 3. Bagaimana tingkat kesulitan adposisi bahasa Jepang berdasarkan interferensi yang muncul pada bahasa tulis mahasiswa angkatan 2010 sastra Jepang Universitas Brawijaya-Malang.

\section{Metode Penelitian}

Penelitian ini menggunakan metode campuran sekuensial, yaitu setelah dilakukan metode kualitatif berupa pendeskripsian jenis kesalahan gramatikal, kemudian dilanjutkan metode kuantitatif yang menunjukkan frekuensi kesalahan terbanyak terhadap penggunaan adposisi bahasa Jepang, yang kemudian diperingkatkan kesulitannya berdasarkan frekuensi kesalahan. Penelitian diawali dari metode kualitatif menuju kuantitatif.Metode kualiatatif terdiri dari kegiatan pengumpulan data, kemudian analisia data. Sedangkan metode kuantitatif terdiri dari proses uji validasi dan reliabilitas, serta pengumpulan data numerial, Kegiatan diakhiri dengan interpretasi keseluruhan analisis, yaitu baik analisis kualitatif maupun kuantitatif.

Sumber data dalam penelitian ini adalah mahasiswa sastra Jepang angkatan 2010 universitas Brawijaya Malang berjumlah 60 siswa.Sedangkan data yang digunakan adalah kalimat yang mengandung adposisi salah yang disebabkan interferensi B1 dalam kalimat yang dibuat oleh mahasiswa, serta jawaban interview yang digunakan sebagai informasi tambahan untuk meng- indentifikasi kesalahan yang disebabkan oleh interferensi B1.

Dalam penelitian pendidikan instrument yang digunakan sering disusun sendiri termasuk menguji validitas dan realibilitasnya. Untuk itu dalam penelitian ini instrument yang berbentuk tes dibuat sendiri oleh peneliti. Instrumen dalam penelitian ini ada dua yaitu: 1.Test : digunakan untuk mencari adposisi bahasa Jepang yang salah yang dilakukan oleh siswa. Kisi-kisi instrumen untuk tes ini adalah, bahwa dalam semua soal membuat kalimat bahasa Jepang, jawaban yang berupa adposisi yang digunakan dalam kalimat tersebut harus memenuhi semua jenis adposisi bahasa Jepang, yaitu wa, ga, mo, ni, de, to, ya, dake/shika, kara, made,o, e,no dan semua peran semantik adposisi tersebut dalam kalimat yaitu 57fungsi sintaksis dan peran semantik. 2. Folow up Interview: Dilakukan pada siswa yang melakukan kesalahan penggunaan adposisi. Interview digunakan untuk memastikan penyebab dilakukannya kesalahan yaitu disebabkan oleh interferensi atau bukan. Jenis interview yang digunakan adalah interview terbuka. Pertanyaan difokuskan pada soal-soal yang jawabannya salah. Untuk itu interview hanya dilakukan pada siswa yang melakukan kesalahan dalam menjawab soal. Untuk uji validitas dan realibilitas dilakukan pada kelas lain diluar subjek penelitian sebanyak 30 siswa. Uji validitas menggunakan t-Tes, sedangkan uji realibilitas dilakukan dengan melihat Koefisien Alpha dengan melakukan Reliability Analysis dengan SPSS ver. 16.0 for Windows.

Karena penelitian ini merupakan penelitian campuran, maka dilakukan dua teknik pengumpulan data, yaitu teknik pengumpulan data kuantitatif, dan teknik pengumpulan data kualitatif. Teknik pengumpulan data kuantitatif dilakukan dengan cara pemberian test kepada siswa. Sedangkan teknik pengumpulan data 
kualitatif adalah dengan sistem dokumentasi atau catat. Setelah siswa mengerjakan test, ditulis ulang jawaban jawaban yang salah dalam lembar terpisah oleh peneliti. Data ditulis ulang untuk memudahkan dalam memberikan pertanyaan kepada siswa dalam sesi interview.

Teknik analisis data dilakukan dengan cara: 1. Hasil test yang dikerjakan siswa diambil jawaban yang salah. 2. Melakukan interview kepada siswa yang jawabannya salah, dengan menanyakan alasan penggunaan adposisi pada tes yang mereka kerjakan.Jawaban interview digunakan untuk mengidentifkasi dan memilah hasil test adposisi. Yang bukan termasuk interferensi dibuang. 3. Menganalisa tiap-tiap kesalahan penggunaan adposisi sesuai dengan teori bahasa Jepang dan bahasa Indonesia. Kegiatan ini bertujuan untuk mencari penyebab kesalahan serta mengetahui jenis interferensi hubungan gramatikal. 4. Mendeskripsikan kesalahan yang dilakukan siswa untuk menghasilkan sebuah penjelasan yang berguna bagi pengajaran. 5. Dari analisa pada point 3 dapat menentukan adposisi apa yang termasuk ke dalam interferensi hubungan gramatikal. 6. Menghitung frekuensi kesalahan tiap-tiap adposisi guna memeringkatkan tingkat kesulitan sesuai dengan jenisnya yaitu overdifferensiasi, konvergensi, dan transfer berdasarkan adposisi yang frekuensi kesalahannya tertinggi. 8. Mendeskripsikan hasil peringkat, serta penyebabnya. 9. Mengevaluasi kesalahan dengan cara mencari letak kesalahan yang paling banyak, sehingga dapat menjelaskan bagian-bagian yang dijadikan pusat perhatian dalam pengajaran adposisi bahasa Jepang.

\section{Hasil Penelitian dan Pembahasan}

\section{Hasil Penelitian}

Dari test yang berupa membuat kalimat bahasa Jepang, setelah dilakukan analisis kesalahan serta dipastikan dengan jawaban interview siswa, maka didapatkan kesalahan yang dibuat oleh siswa terdapat pada kalimat di bawah ini:

Tabel 3.1 Hasil Test Membuat Kalimat Bahasa Jepang yang terdapat Kesalahan karena Interferensi B1 pada Adposisi Bahasa Jepang

\begin{tabular}{|c|c|c|c|c|}
\hline No & Adposisi & Peran semantik, sintaksis & Kalimat & Jumlah \\
\hline \multirow[b]{2}{*}{1} & \multirow[b]{2}{*}{ wa } & Menunjukkan topic & $\begin{array}{l}\text { Nihon deØdensha o tsukau } \\
\text { hito ga ooi desu. }\end{array}$ & 17 \\
\hline & & Penegasan & $\begin{array}{l}\text { Kono heya nara, } 30 \text { nin mo } \\
\text { hairemasu. }\end{array}$ & 8 \\
\hline 2 & mo & Penekanan & Zenzen yasumikatta. & 1 \\
\hline \multirow{2}{*}{3} & \multirow[b]{2}{*}{$\mathrm{ga}$} & Menyatakansubjek & $\begin{array}{l}\text { Kono keekiwa watashi no } \\
\text { tsukutta keeki desu. }\end{array}$ & 8 \\
\hline & & Penandamodifikator & $\begin{array}{l}\text { Haha no tsukuttta ryouri ha } \\
\text { oishii. }\end{array}$ & 35 \\
\hline \multirow{3}{*}{4} & \multirow{3}{*}{$\mathrm{O}$} & Tempataktifitas & $\begin{array}{l}\text { Yasumi Øtoki, kouen de } \\
\text { sanpou shimasu. }\end{array}$ & 24 \\
\hline & & $\begin{array}{l}\text { Tempat dilaluinya suatu proses } \\
\text { atau kegiatan }\end{array}$ & $\begin{array}{l}\text { Hikouki wa kuuki de } \\
\text { tobimasu. }\end{array}$ & 14 \\
\hline & & Menyatakan tempat Keberadaan & $\begin{array}{l}\text { Kaban no naka de hon to } \\
\text { enpitsu ga arimasu. }\end{array}$ & 6 \\
\hline
\end{tabular}




\begin{tabular}{|c|c|c|c|c|}
\hline & & Titik sampai & $\begin{array}{l}\text { Uchi made denwa o kakete } \\
\text { kudasai. } \\
\text { Uchi e kitara,denwa shite } \\
\text { kudasai. }\end{array}$ & 8 \\
\hline \multirow{6}{*}{5} & \multirow{6}{*}{ ni } & Tujuan & $\begin{array}{l}\text { Asanebou kara, gakkou e } \\
\text { chikoku shimaimashita. }\end{array}$ & 30 \\
\hline & & Frekuensi & $\begin{array}{l}1 \text { nichi de/Ø/juu } 5 \text { kai oinori } \\
\text { o shimasu. }\end{array}$ & 10 \\
\hline & & Arah & $\begin{array}{l}\text { Kono depaato wa nishi e } \\
\text { mukimasu. }\end{array}$ & 9 \\
\hline & & Taraf keadaan & $\begin{array}{l}\text { Ali san wa nihongo de jouzu } \\
\text { Øhanaseru. }\end{array}$ & 2 \\
\hline & & $\begin{array}{l}\text { Bagian mana kita melakukan } \\
\text { sesuatu }\end{array}$ & Kabe de e o kakete imasu & 10 \\
\hline & & $\begin{array}{l}\text { Pelaku/dari mana suatu hal } \\
\text { didapat }\end{array}$ & $\begin{array}{l}\text { Sensei kara hon o } \\
\text { dipinjami。 }\end{array}$ & 3 \\
\hline & \multirow{4}{*}{ de } & Cara/alat & $\begin{array}{l}\text { Ali san wa nihongo no } \\
\text { kaiwa ga jouzu }\end{array}$ & 2 \\
\hline & & Bahan & $\begin{array}{l}\text { Tsukue wa ki kara } \\
\text { tsukuraremasu. }\end{array}$ & 23 \\
\hline & & Alasan & $\begin{array}{l}\text { Tsunami desukara takusan } \\
\text { hito ga shinimashita. }\end{array}$ & 20 \\
\hline & & Waktu & $\begin{array}{l}\text { Chichi wa } 75 \text { sai ni } \\
\text { shinimashita }\end{array}$ & 28 \\
\hline \multirow{2}{*}{\multicolumn{2}{|c|}{ no }} & $\begin{array}{l}\text { Sifat dari kata benda yang } \\
\text { mengikutinya }\end{array}$ & $\begin{array}{l}\text { Koko kara tsunamiØoto ga } \\
\text { kikoemasu. } \\
\text { YausmiØtoki, kouen ni } \\
\text { arumkimasu. }\end{array}$ & 17 \\
\hline & & Penghubung tempat & $\begin{array}{l}\text { Kaban ni hon to enpitsu ga } \\
\text { arimasu }\end{array}$ & 1 \\
\hline
\end{tabular}

Jika dilihat dari keseluruhan adposisi, maka akan didapat hasil seperti di bawah ini: 


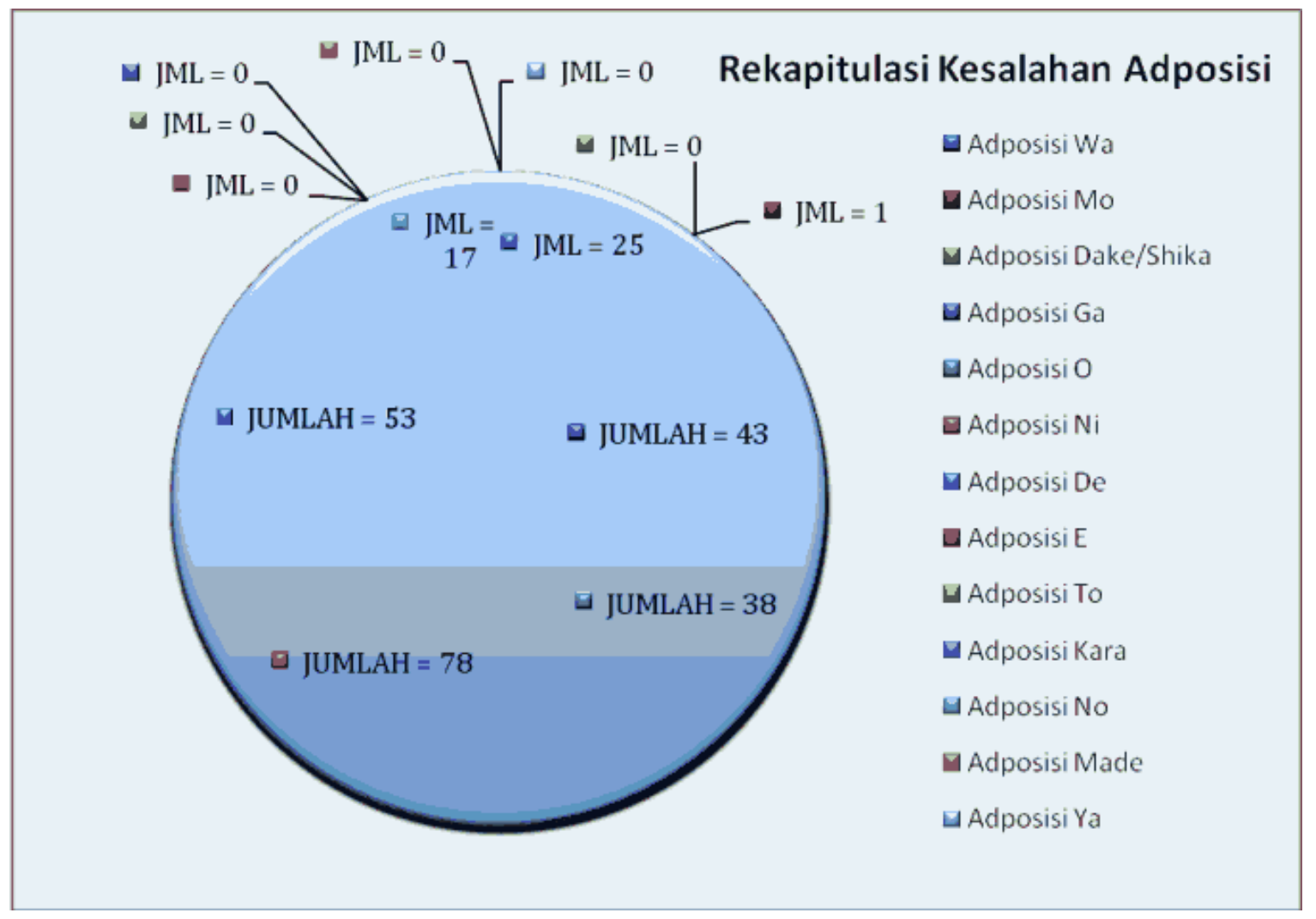

\section{Diagram 3.1 Total Kesalahan Adposisi karena Interferensi Bahasa Indonesia}

Dari hasil analisa kesalahan adposisi yang disebabkan interferensi, diketahui bahwa hanya terjadi transfer hubungan gramatikal B1 melanggar pola hubungan gramatikal B2, yaitu transefer hubungan yang melanggar pola B2, namun masih bisa dimengerti secara tersirat.Transfer hubungan gramatikal ini terdapat pada kalimat :

1. Ayah meninggal pada usia 75 tahun $=$ Chichi wa 75 sai ni shinimashita.

2. Terlambat kesekolah karena terlambat bangun =Asanebou kara, gakkou e chikoku shimaimashita.

3. Pesawat terbang di udara $=$ Hikouki wa kuuki de tobimasu.

4. Menggantung lukisan di dinding = Kabe de e o kakete imasu.

5. Ketika libur jalan-jalan di taman $=$ YasumiØ toki, koen de/e sanpou shimasu.
6. Kalau sampai rumah tolong telepon $=$ Uchi e/made kitara, denwa shite kudasai.

7. Departemen store ini menghadap ke barat $=$ kono depaato wa nishi $\mathrm{e}$ mukimasu.

8. Dalam sehari sembahyang $5 \mathrm{kali}=1$ nichi de/Ø 5 kai oinori o shimasu.

9. Keluar rumah pukul $6: 30=6 \mathrm{ji} 30$ pun ni uchi kara demasu.

10. Di dalam tas ada buku dan pensil = kaban no naka de hon to enpitsu ga arimasu

Dari kalimat-kalimat di atas, diketahui bahwa interferensi terjadi pada transfer hubungan gramatikal pada adposisi $n i, e$, de, $o$ dan $n o$.

Tingkat kesulitan berdasarkan interferensi bahasa ibu yang digunakan dalam penelitian adalah dounyuu loverdferensiasi (0-1); tougou /konvergensi (2-1) : taiou /transfer (1-1). Adposisi yang 
termasuk dounyuu/overdifferensiasi (0-1) adalah wa,yang termasuk tougou /konvergensi (2-1) adalah mo, ga, o, ni, de, no, to.yang termasuk taiou /transfer (1-1) adalah $e$, kara, made, ya. Dari hasil tes diketahui bahwa kesalahan karena interferensi muncul pada adposisi wa sebanyak 25 orang. Berarti tingkat kesulitan dounyuu/overdifferensiasi (0-1) sebanyak 25 kesalahan. Untuk tingkat kesulitan tougou /konvergensi (2-1) diketahui terdapat kesalahan pada partikel mo, ga,o, ni, de, no sebanyak 230 kesalahan Sedangkan untuk tingkat kesulitan taiou /transfer (1-1), tidak ditemukan kesalahan.. Sehingga tingkat kesulitan adposisi bahasa Jepang berdasarkan interferensi bahasa Indonesia tersusun atas:

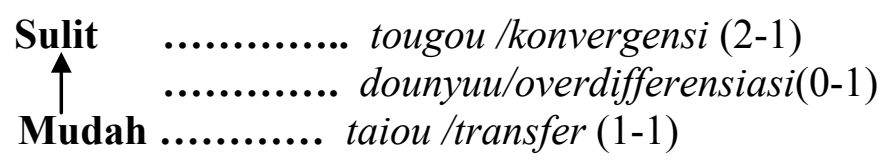

\section{Pembahasan}

Adposisi wa adalah adposisi yang pertama kali dipelajari siswa yaitu yang berfungsi sebagai topik. Sehingga seringkali ditemukan bahwa setiap kalimat yang dibuat siswa, setelah subjek, langsung diisi oleh adposisi wa.Sehingga dapat dikatakan bahwa meskipun adposisi wa tidak ada padanannya dalam bahasa Indonesia, tidak banyak siswa yang merasa kesulitan. Namun dari hasil test yang dilakukan didapat kesalahan adposisi wa sebanyak 17. Siswa tidak menggunakan partikel wa pada kalimat "Di Jepang, orang yang menggunakan kereta listrik banyak". Siswa membuat kalimat dalam bahasa Jepang Nihon deØdensha o tsukau hito ga ooi desu (Di jepang orang yang memakai kereta api banyak). Alasan yang dikemukakan mengapa tidak memakai partikel $w a$ antara lain adalah karena koma saja sudah cukup maka artinya sama saja; tidak perlu karena teks bahasa Indonesia hanya "Di Jepang" saja, tidak ada yang lain.

Dari alasan yang dikemukakan siswa, terlihat bahwa, kalau pada teks bahasa Indonesia tidak terdapat kata yang harus diterjemahkan, maka kecil kemungkinan siswa menyadari bahwa pada bagian tersebut dibutuhkan sebuah adposisi. Peran sintaksis adposisi wa yang menyatakan topik memang tidak terdapat dalam bahasa Indonesia. Sebagai gantinya biasanya digunakan bunyi senyap diatara dua kata tersebut.Karena merupakan bahasa tulis, maka bunyi senyap ditampilkan dengan menggunakan tanda koma.Penggunaan kaku joshi dan toritate joshi secara bersamaan memang dimungkinkan dalam bahasa Jepang. Jika hanya memakai adposisi de, maka kalimattersebut merupakan kenyataan secara obyektif (kyakkan teki na jijitsu) . Sedangan jika diberi tambahan wa, maka kalimat tersebut salah satu bagian dari keyataan secara obyektif yang diambil untuk dijadikan topik (Iori, 2004:315).

Pada kesalahan adposisi wa dengan peran semantik penegasan, terdapat 8 kesalahan. Ini terdapat pada kalimat "Kalau ruangan ini, 30 orang bisa masuk". Siswa membuat kalimat bahasa Jepang Kono heya nara 30nin mo hairemasu (Kalau ruangan ini 30 orang bisa masuk). Alasan yang dikemukakan adalah untuk penekanan. Karena penekanan itu dalam bahasa Indonesia pun, maka dipilihlah adposisi mo. Jika dilihat dari kalimat bahasa Indonesia, sekali lagi dapat dilihat bahwa tidak terdapat adposisi yang harus diterjemahkan ke dalam bahasa Jepang. Hal ini berpulang pada kemampuan siswa dalam memahami konteks kalimat 
sehingga bisa menentukan adposisi apa yang seharusnya digunakan. Oleh sebab itu, hanya ada 8 siswa yang memahami bahwa kalimat ini adalah penegasan, meskipun mereka salah dalam memilih adposisi. Sedangkan siswa lain memilih adposisi $g a$ karena bisa masuk merupakan kalimat potensial (kanoukei).

Adposisi mo secara makna mudah dimengerti oleh siswa karena maknanya sejajar dengan kata juga.Sedangkan untuk makna penekanan, adposisi mo sejajar dengan partikel pun.Makna partikel pun dapat juga bermakna juga seperti dalam kalimat saya pun mau.Karena itu dua peran ini mudah dimengerti olah siswa.Jadi dapat juga dikatakan bahwa adposisi mo bukanlah adposisi yang sulit. Namun ternyata ditemukan 1 siswa yang melakukan kesalahan adposisi mo yang menyatakan penekanan. Ini terdapat pada teks "Tidak pernah bolos sekalipun". Siswa membuat kalimat bahasa Jepang Zenzen yasumikatta (Sama sekali tidak libur).Siswa tidak menggunakan adposisi namun menggunakan adverbia zenzen.Alasan yang dikemukakan adalah sekalipun adalah sama dengan sama sekali. Jika dikembalikan pada analisis kontrastif, tidak ada perbedaan untuk peran semantik penekanan pada adposisi mo dan partikel pun.siswa yang melakukan kesalahan tersebut tidak membuat kata sekalipun menjadi ichido mo, tetapi menggunakan adverbia. Hal ini dikarenakan siswa membuat kesimpulan sendiri terhadap kata sekalipun yang dianggapsama dengan sama sekali.

Dalam bahasa Indonesia, adposisi ga dapat disejajarkan maknanya dengan kata nya dan yang. Ini berarti adposisi ga dalam bahasa Indonesia mempunyai fungsi menyatakan milik serta sebagai penyambung subjek dan predikat. Namun tidak semua kalimat yang menggunakan adposisi $g a$, dapat diterjemahkan maknanya sebagai nya ataupun yang.
Misalnya, dalam kalimat watashi wa ryouri ga jouzu desu yang dalam bahasa Indonesia berarti Saya pandai Ø memasak.

Pada adposisi ga, terjadi kesalahan pada dua fungsi, yaitu menyatakan subjek dan penanda modifikator. 8 kesalahan apdosisi gayang menyatakan subjek. Terdapat dalam kalimat "Cake ini saya yang buat". Siswa membuat kalimat bahasa Jepang, kono keeki wa watashi no tsukutta keeki (cake ini adalah cake buatan saya). Semua siswa mengemukakan alasan yang sama dalam menggunakan adposisi no, yaitu karena saya yang membuat maka sama dengan milik saya. Kalimat di atas bukan termasuk kalimat yang menyatakan bahwa subjek melakukan perbuatan membuat cake.Penggunaan adposisi no dalam kalimat tersebut menyatakan modifikator.Fenomena adposisiga yang menyatakan subjek, sama dengan fenomena yang terjadi pada adposisi ga yang mempunyai peran sintaksis membentuk modifikator, dimana terdapat 35 orang yang melakukan kesalahan. Kesalahan ada pada kalimat "Masakan yang dibuat ibu enak", dibuat ke dalam bahasa Jepang menjadi Haha no tsukutta ryouri wa oishii (Masakan buatan ibu enak). Alasan yang dikemukan siswa semua sama yaitu karena masakannya milik ibu. Sedangkan dalam bahasa Indonesia sendiri kata yang merupakan partikel yang juga diletakkan antara subjek dan predikat. Fungsi yang dalam kalimat tersebut adalah menegaskan/menerangkan bahwa masakan tersebut adalah buatan ibu.Dan bukan kalimat yang menyatakan milik.Hal ini terlihat jelas bahwa peran sintaksis adposisi ga yang padanan dalam bahasa Indonesia adalah yang, cenderung diasumsikan siswa sebagai milik. Karena milik maka siswa akan memilih adpsosi no. Secara teori, adposisi no dapat menggantikan adposisi ga pada peran sintaksis membentuk modifikator, karena salah satu peran sintaksis adposisi no 
adalah juga untuk membentuk modifikator.Ini dapat dibuktikan pada adpsisi no yang berperan sebagai pembentuk modifikator tidak ditemukan satu orang pun yang melakukan kesalahan. Namun tidak semua adposisi ga sebagai modifikator bisa diganti dengan adposisi no. Misalnya dalam kalimat Tarou ga natsu yasumi ni isshoukenmei kaita tegami (Surat yang ditulis Taro dengan bersugguh-sungguh pada musim panas). Menurut Iori (2004:184) jika di antara noun frase dan noun modifier,diisi oleh bermacam-macam frasa, maka penggunaan adposisi no, akan menimblkan ketidakalamian (fushizen).

Adposisi $o$ dalam bahasa Indonesia sejajar dengan makna di dan dari, tapi ada juga yang tidak bermakna. Adposisi $o$ yang tidak ada maknanya dalam bahasa Indonesia inilah yang lebih dahulu dipelajari siswa. Dan siswa terlanjur menyimpulkan bahwa adposisi $o$ digunakan untuk menyambung kata kerja transitif dengan objek yang ada di depannya.Dari hasil test, untuk adposisi $o$ terdapat 24 kesalahan untuk peran semantik tempat aktivitas. Kesalahan ini ada pada kalimat,"Ketika libur jalan-jalan di taman" yang oleh siswa dibuat kalimat bahasa Jepang menjadi, Yasumi Øtoki, koen de sanpou shimasu. Alasan yang dikemukakan karena di taman adalah tempat, maka adposisi yang digunakan $d e$. Sebenarnya menggunakan apdosisi de pada kalimat ini tidak salah, karena baik adposisi $o$ dan de sama-sama menyatakan tempat aktifitas. Perbedaannya adalah kalau $o$ lebih focus pada kegiatan jalanjalan (mengelilingi taman) sedangkan de focus pada tempat. Namun untuk menguji, apakah siswa memahami apdosisi $o$ yang berperan sebagai tempat aktivitas, maka dibuatlah kalimat seperti di atas.Mengapa demikian, karena tidak semua kalimat yang menggunakan adposisi de bisa diganti dengan adposisi $o$, seperti pada kalimat toshokan de benkyou shimasu (Belajar di perpustakaan), jika menggunakan adposisi o menjadi Toshokan o benkyou shimasu maka maknanya adalah belajar (mengenai) perpustakaan.

Begitu juga untuk adposisi $o$ yang mempunyai peran semantik sebagai tempat dilaluinya suatu proses. Terdapat 14 kesalahan, yaitu pada kalimat, "Pesawat terbang di udara", yang dibuat ke dalam bahasa Jepang menjadi, Hikouki wa kuuki de tobimasu. Seluruh siswa mengemukakan alasan yang sama, yaitu karena di udara. Seluruh siswa yang menjawab de tidak menyadari atau lupa bahwa $o$ 'dapat berarti di'dalam bahasa Indonesia. Juga siswa tidak memahami peran lain dari adposisi $o$. Siswa hanya tahu kalau adposisi $o$ adalah adposisi untuk kata kerja transitif. Untuk itulah pada peran sematik titik awal aktifitas yang ditunjukkan pada kalimat "Keluar rumah pukul 6:30", terdapat 3 siswa yang membuat kalimat, Uchi kara 6ji han ni demasu. Siswa memilih adposisi kara karena berfikir bahwa keluar rumah berarti keluar dari rumah. Adposisi kara memang memiliki peran semantik titik awal, namun bukan sebagai awal dari aktifitas. Juga karena ada siswa yang berfikir bahwa adposisi $o$ sebagai adposisi yang digunakan pada verba transitif, sedangkan keluar merupakan verba intransitiv, maka pilihan jatuh pada adposisi kara.

Untuk adposisi $n i$ yang mempunyai peran semantik menyatakan tempat keberadaan terdapat 6 orang yang melakukan kesalahan, yaitu pada kalimat,"Di dalam tas ada buku dan pensil", yang oleh siswa dibuat bahasa Jepang menjadi, Kaban no naka de hon to enpitsu ga arimasu. Alasan yang dikemukakan adalah karena di dalammaka adposisi yang digunakan adalah de.Padahal untuk menunjukkan keterangan tempat yang tidak terdapat kegiatan adalah ni. Sebenarnya untuk perbedaan adposisi yang 
menyatakan tempat keberadan dan tempat aktivitas dalam konteks kalimat di atas sudah cukup jelas. Namun, seperti yang telah dijelaskan sebelumnya bahwa ada siswa yang kesetiaan terhadap B1 terlalu kuat, maka B1 selalu muncul, meskipun kemunculan tersebut dikarenakan faktor lupa, hal tersebut terjadi karena B1 terlalu kuat. Kecuali untuk beberapa verba yang menunjukkan aktivas, ada juga yang menggunakan adposisi $n i$. Misalnya $I s u$ ni suwatte imasu (duduk di kursi), atau verba aru yang menyatakan keberadaan tetapi menggunakan adposisi de, misalnya dalam kalimat bijutsukan de tenrankai ga aru (di museum ada pameran). Menggunakan adposisi $n i$ karena duduk merupakan shunkan doushi (aktivitas sekejap), sedangkan menggunakan adposisi de, karena pameran adalah sebuah aktivitas. Kecenderungan memilih de sebagai tempat ini sama dengan hasil penelitian Saito Matsuda (1992) terhadap pembelajar Bahasa Jepang yang ber B1 bahasa Korea. Dan berbeda dengan hasil penelitian Mizutani Nobuko (1987) yang meneliti pembelajar bahasa Jepang yang ber B1 bahasa Inggris, dimana siswa cenderung memeilih adposisi $n i$ untuk tempat aktivitas.

Untuk peran semantik yang menyatakan titik sampai terdapat pada kalimat, "Kalau sampai rumah tolong telepon", terdapat 8 siswa yang melakukan kesalahan. Siswa membuat kalimat dalam bahasa Jepang, Uchi made denwa o kakete kudasai, uchi e kitara, denwa shite kudasai. Alasan yang dikemukanan adalah karena sampai rumah adalah pulang ke rumah, maka adposisi yang dipilih $e$. Hal ini pada akhirnya akan berpulang kembali kepada si pembicara atau yang membuat kalimat. Adposisi e mempunyai makna menyatakan arah.Kalimat sampai rumah ataupun pulang ke rumah bisa bermakna arah yaitu menuju ke rumah. Sehingga jika pembicara fokus pada arah maka dia akan cenderung menggunakan $e$, jika fokus pada rumah maka menggunakan ni. Namun bukan berarti kalimat yang dibuat siswa bisa dibenarkan.Karena kalimat pada soal bermakna titik sampai bukan arah.Verba yang dikehendaki pun bukan kimasu (datang) tetapi tsukimasu (sampai).

Siswa yang menggunakan adpsosisi made karena merujuk pada kata sampai. Adposisi made sendiri mempunyai makna batasan. Jadi tidak benar jika sampai rumah merupakan suatu batasan. Jadi kesalahan yang dilakukan siswa dengan menggunakan adposisi made ini karena siswa menggunakan kalimat sederhana dengan mengartikan bahwa sampai adalah made.

Untuk peran semantik menyatakan tujuan yang terdapat pada kalimat "Terlambat ke sekolah karena terlambat bangun", terdapat 30 kesalahan dengan kalimat,Asanebou kara, gakkou e chikoku shimaimashita. Alasan yang dikemukakan semua sama, yaitu karena menuju ke sekolah. $\mathrm{Ke}$ menurut Anton Mulyono dan Chaer adalah menunjukkan arah tujuan, sedangkan untuk fungsi tujuan itu sendiri digunakan preposisi untuk, buat, guna, bagi. Dalam bahasa Jepang adposisi $n i$ mempunyai peran semantik mokuteki (tujuan), sedangkan $e$ adalah houkou (arah). Dua fungsi yang berbeda tetapi karena dalam pemakaiannya adakalanya bisa saling menukar, menyebabkan siswa sering memilih apdosisi yang paling mirip dalam bahasa Indonesia. Sehingga dalam kalimat misalnya gakkou e ikimasu, sedikit siswa memilih adposisi $n i$.

Sepuluh siswa melakukan kesalahan untuk peran semantik frekuensi ditunjukkan dalam kalimat "Dalam sehari sembahyang 5 kali". Mereka membuat kalimat Ichi nichi de/Ø / juu 5kai ni oinori $o$ shimasu. Alasan yang dikemukakan adalah, karena dalam adalah de; tanpa adposisi maknanya sudah jelas karena ichi nichi adalah satu hari; serta menggunakan 
kata juu yang artinya juga dalam satu hari. Fungsi semantik dalam dalam bahasa Indonesia adalah tempat. Tetapi ada juga yang menyatakan frekuensi. Karena itu siswa juga memilih adposisi de untuk kalimat di atas.Sedangkan siswa yang tidak menggunakan adposisi, dikarenakan kesalahan dalam memahami makna dari kata ichi nichi itu sendiri.Kata juusendiri dalam ichi nichi juubermakna sehari penuh.

Terdapat 9 siswa yang melakukan kesalahan pada fungsi semantik arah yang ditunjukkan dalam kalimat "Department Store ini menghadap ke barat". Siswa membuat kalimat, Kono depaato wa nishi e mukimasu. Dalam bahasa Indonesia, fungsi semantik arah tujuan ditunjukkan dengan preposisi ke, kepada, akan, terhadap. Untuk itu tidak salah jika siswa memilih adposisi e.Namun perlu diingat sekali lagi bahwa adpsosisi e bukan berperan sebagai arah tujuan tapi arah aktifitas. Tidak adanya pembedaan antara arah tujuan dan arah aktifitas dalam bahasa Indonesia ini membuat siswa mengeneralisasi pemakaian adposisi.

Untuk peran semantik taraf keadaan yang ditunjukkan dalam kalimat "Ali pandai bicara dalam bahasa Jepang" terdapat 2 siswa yang melakukan kesalahan. Sebenarnya, kalimat yang dibuat siswa tidak salah, namun jika disesuaikan dengan bahasa Indonesia yang diminta, menghasilkan kalimat yang sedikit berbeda namun maknanya mirip yaitu Ali san wa nihongo de hanaseru koto wa jouzu (Ali bisa bicara dalam bahasa Jepangnya pandai), dan Ali san wa nihongo de hanashi ga jouzu (Ali bicara dalam bahasa Jepangnya pandai). Sehingga ketika peneliti bertanya "Apa bahasa Jepangnya 'pandai bicara?", siswa menjawab Jouzu hanashimasu. "Mengapa tidak menggunakan adposisi?", siswa menjawab. "Tidak perlu". Terlihat lagi bahwa sulit menentukan adposisi yang dipakai di antara dua kata, jika dalam bahasa Indonesia tidak ada kata yang bisa mengkespresikannya. Namun jika siswa ingat pada perubahan adjective bahwa jika naadjective bergabung dengan verba, maka harus diikuti oleh adposisi $n i$ tentunya tidak mengalami kesulitan untuk membuat frasa pandai bicara.

Pada peran semantik bagian mana kita melakukan sesuatu, yang ditunjukkan dalam kalimat "Menggantung lukisan di dinding" terdapat 10 siswa yang melakukan kesalahan. Siswa membuat kalimat kabe de e o kakete imasu.Dalam bahasa Indonesia, baik preposisi $d i$ dan pada menyatakan tempat. Namun karena siswa cenderung membuat terjemahan bahwa $d i=d e$ dan $n i=p a d a$, maka akan selalu didapat jawaban bahwa alasan memakai adposisi de adalah karena $d i$.

$$
\text { Hanya terdapat 3siswa yang }
$$

melakukan kesalahan untuk peran semantik pelaku/darimana suatu hal didapat. Kalimat "Dipinjami buku oleh guru", menjadi, Sensei kara hon o dipinjami. Alasan yang dikemukakan sama, yaitu karena dari=kara. Dalam bahasa Jepang baik ni maupun kara mempunyai makna semantik yang sama untuk peran ini. Yang membedakannya adalah nipelakunya adalah individu, sedangkan kara adalah sebuah instansi.

Adposisi de merupakan adposisi yang mudah diingat siswa karena mirip dengan didan dalam dalam bahasa Indonesia.Karena kemiripan tersebut, bisa mengakibatkan overgeneralisasi.Untuk peran semantik cara/alat terdapat 2 kesalahan. Dalam kalimat "Ali pandai bicara dalam bahasa Jepang", siswa membuat kalimat Ali san wa nihongo no kaiwa ga jouzu.Kalimat ini secara sintaksis dan semantik tidak salah, namun sedikit berbeda dengan makna yang dikehendaki dalam kalimat bahasa Indonesia. Ketika peneliti bertanya nihongo no kaiwa digunakan untuk menerjemahkan frasa apa, siswa menjawab "Bicara dalam bahasa 
Jepang itu kan nihongo no kaiwa". Dari jawaban siswa ini, dapat dilihat bahwa jika siswa kesulitan untuk membuat kalimat yang sesuai dengan pertanyaan yang diajukan, maka siswa cenderung membuat kalimat yang dia kuasai dan yang lebih mudah.Fenomena ini juga yang mengakibatkan tidak terdapat variasi pada karangan yang dibuat siswa.Meskipun sudah belajar pola-pola baru maupun katakata baru, siswa tetap membuat kalimat yang paling mudah dan sederhana yang terkadang kalimat yang dihasilkan berbeda maknanya dari yang dipikirkan siswa.

Pada peran semantik yang menyatakan bahan, terdapat 23 kesalahan. Kalimat "Meja terbuat dari kayu", oleh siswa dibuat kalimat menjadi Tsukue wa ki kara tsukurimashita (Meja, membuat dari kayu). Peran semantik kara dan de samasama menyatakan bahan, tetapi untuk de, bahan asal masih keliahatan wujudnya. Siswa yang mengalami interferensi, dengan cepat menjawab dipakainya adposisi kara karena kara adalah dari. Sedangkan siswa yang tidak mengalami interferensi, meskipun adposisi yang digunakan salah, mereka akan mengatakan bingung atau lupa, mana yang harus pakai kara mana yang harus pakai de.

Untuk peran semantik yang menyatakan alasan, terdapat 20 kesalahan. Kalimat "Banyak orang mati karena tsunami", oleh siswa dibuat menjadi Tsunami desu kara, takusan hito ga shinimashita. Alasan yang dikemukakan rata-rata sama yaitu kara adalah karena. De dan kara sama-sama menyatakan sebab/alasan tetapi dengan fokus yang berbeda. Pada kalimat di atas, kalimat fokus pada shinda hito ga ooi(orang yang meninggal banyak) untuk itu menggunakan adposisi de. Kalau menggunakan kara, maka terasa aneh, karena kalimat tersebut akan bermakna banyak orang yang mati karena tsunami, tetapi kalau bukan karena tsunami, mungkin tidak banyak orang yang mati. Dan juga kalau memakai kara, lebih cenderung subyektifitas pembicara.

Sedangkan untuk peran yang menyatakan waktu, terdapat 28 siswa yang melakukan kesalahan, yaitu pada kalimat "Ayah meninggal pada usia 75 tahun" oleh siswa dibuat kalimat menjadi Chichi wa 75 sai ni shinimashita.Alasan yang dikemukakan adalah karena pada sama dengan $n i$. Kalau dilihat dari teori bahasa Indonesia, preposisi yang menyatakan waktu adalah pada, hingga, sampai, sejak, semenjak, menjelang. Jadi baik dalam bahasa Indonesia, maupun bahasa Jepang kalimat ini mempunyai makna yang sama, yaitu waktu. Namun bahasa Jepang tidak ditunjukkan dengan adposisini tetapi dengan adposisi $d e$.

Pada peran semantikyang menyatakan sifat benda yang mengikuti terdapat 17 kesalahan. Pada kalimat "Dari sini terdengar bunyi ombak" menjadiKoko kara nami Ø oto ga kikoemasu, kalimat "Ketika libur, jalan-jalan di taman" menjadi Yasumi Ø toki kouen de sanpo shimasu. Rata-rata siswa mengemukakan alasan tidak perlu adposisi pada kalimat tersebut. Ada pula yang beralasan bahwa toki sudah menyatakan ketika, sehingga tidak perlu adposisi juga tidak mengapa. Hal ini juga merupakan fenomena yang sering terjadi yakni jika tidak ada kata yang bisa diekspresikan dalam bahasa Indonesia, siswa cenderung tidak menggunakan adposisi, atau siswa mengalihkan ke dalam kata yang artinya sama.

Yang terakhir adalah peran penghubung tempat yang dinyatakan dalam kalimat "Di dalam tas ada buku dan pensil", terdapat 1 kesalahan. Siswa membuat kalimat Kaban ni hon to enpitsu ga arimasu. Kesalahan yang terdapat pada kalimat ini tidak pernah diperkirakan sebelumnya, karena kalimat jenis ini adalah kalimat yang paling mudah sehingga hampir semua siswa bisa 
membuatnya. Ketika ditanya alasannya, siswa menjawab "karena di tas". Ketika dikejar lagi dengan pertanyaan "dalam nya mana?", siswa menjawab "sama saja". Menyingkat kalimat panjang menjadi lebih sederhana merupakan salah satu cara siswa jika kesulitan dalam membuat kalimat. Apalagi dalam bahasa Indonesia, membuat kalimat di tas siapa pun bisa mengerti bahwa yang dimaksud adalah di dalam tas.

Seperti yang dikemukakan oleh Weinreich bahwa di dalam interferensi gramatikal terdapat 3 jenis interferensi hubungan gramatikal.Pada penelitian ini, setelah dilakukan analisis kesalahan berdasarkan analisis kontranstif, maka hanya didapatkan jenis interferensi hubungan gramatikal yaitu transfer hubungan gramatikal B1 melanggar pola hubungan gramatikal B2namun masih bisa dimengerti secara tersirat. Interferensi hubungan gramatikal ini terjadi pada adposisi $n i, e, d e, o$ dan no.Ke lima adposisi yang digunakan dalam kalimat di atas adalah salah atau melanggar gramatika bahasa Jepang, namun masih bisa dimengerti secara tersirat. Mengapa demikian, karena adposisi salah yang dipilih oleh siswa memang mempunyai peran semantik yang sama dengan adposisi yang seharusnya digunakan, tetapi dalam konteks kalimat yang berbeda. Serta adanya kemiripan bunyi seperti adposisi de dan kara yang juga hampir sama artinya dalam bahasa Indonesia, sehingga membuat siswa mudah mengingatnya, dan selalu kata tersebut yag muncul pertama kali ketika siswa membuat kalimat dalam bahasa Jepang.

Seperti yang telah dikemukakan sebelumnya, ada siswa yang merasa mudah jika terdapat kesamaan pada B1 dan B2, ada pula siswa yang justru merasa sulit jika aspek pada B1 dan B2 sama. Dalam kasus bahasa Jepang dan bahasa Indonesia ini, ke dua fenomena ini semua berperan. Siswa merasa mudah karena ada beberapa adposisi bahasa Jepang mirip dengan bahasa Indonesia. Namun karena mempunyai peran semantik yang banyak, maka siswa cenderung membuat generalisasi untuk semua konteks kalimat.Jika kita melihat kembali peran semantik adposisi ni,e,de,o, dan noini, dapat dilihat bahwa:

1. Peran semantik adpsoisi $n i$ yang sama dengan adposisi de adalah menyatakan tempat, waktu, sebab/alasan.

2. Peran semantik adposisi $n i$ yang sama dengan adpsosisi $e$ adalah arah

3. Peran semantik adposisi de yang sama dengan adposisi o adalah tempat aktifitas

4. Peran semantik adposisi $n i$ yang sama dengan adposisi kara adalah pelaku/dari mana suatu hal di dapat (menerima sesuatu dari lawan bicara)

5. Peran semantik adposisi de yang sama dengan adposisi kara adalah sebab/alasan dan bahan.

6. Peran semantik adposisi o yang sama dengan adposisi kara adalah titik awal.

Dari hasil analisa kontranstif bahasa Jepang dan bahasa Indonesia diketahui bahwa tingkat kesulitan karena interferensi bahasa Indoneisa yang terdapat pada adpsosisi bahasa Jepang adalah dounyuu/overdferensiasi (0-1); tougou /konvergensi (2-1) : taiou/transfer (1-1). Dari hasil analisa kesalahan pada kalimat yang dibuat siswa, diketahui bahwa terdapat tingkat kesulitan dounyuu/overdifferensiasi (0-1) sebanyak 25 kesalahan. Untuk tingkat kesulitan tougou /konvergensi (2-1) sebanyak 230 kesalahan (ini adalah akumulasi dari jumlah kesalahan yang terdapat pada adposisi $m o, g a, o, n i$, de, no,) sedangkan untuk tingkat kesulitan taiou /transfer (11), tidak ditemukan kesalahan. Sehingga tingkat kesulitan adposisi bahasa Jepang tersusun atas taiou $\rightarrow$ dounyou $\rightarrow$ tougou . Penelitian terdahulu yang dilakukan oleh Ishida yang membandingkan bahasa Jepang dengan 
bahasa Inggris diketahui ranking tingkat kesulitan karena interferensi B1 adalah :Taiou (1-1) $\rightarrow$ Tougou $\quad$ (2$1) \rightarrow$ Sakujo $(1-0) \rightarrow$ Dounyuu $(0-1) \rightarrow$ Bunka (1-2)

Dapat dilihat bahwa terjadi perbedaan tingkat kesulitan di antara pembelajar bahasa Jepang yang berB1 bahasa Inggris dan berB1 bahasa Indonesia yaitu pada posisi dounyuu/overdifferensiasi dan tougoukonvergensi. Namun hal ini juga tidak bisa dijadikan acuan karena Ishida mencari tingkat kesulitan pada seluruh aspek bahasa, sedangkan penelitian ini hanya mencari tingkat kesulitan pada penggunaan adposisi saja. Meskipun apdosisi wa (dounyuu/overdifferensiasi) lebih sulit dari pada bentuk $\sim$ te iru (tougou/konvergensi), sedangkan pada bahasa Indonesia, tougou/konvergensi lebih sulit dari pada dounyuu/overdifferensiasi, ini juga tidak bisa dijadikan kesimpulan bahwa tougou/konvergensi memang lebih sulit dari pada dounyuu/overdifferensiasi.

\section{Penutup}

Berdasarkan penelitian dan rumusan masalah yang telah dilakukan, dapat disimpulkan bahwa interferensi bahasa Indonesia pada penggunaan adposisi bahasa Jepang dalam kalimat yang dibuat siswa terjadi pada adposisi $w a$, $m o, g a, o, n i, d e$, dan no. Interferensi yang terjadi pada adposisi wa terdapat pada peran sintaksis menunjukkan topik dan peran semantik penegasan. Untuk adposisi mo terdapat pada peran semantik penekanan, adposisi ga terdapat pada peran sintaksis menyatakan subjek dan penanda modifikator. Untuk adposisi $o$ terdapat pada peran semantik tempat aktivitas dan tempat dilaluinya suatu proses/kegiatan. Adposisi niterdapat pada peran semantik titik sampai, tujuan, frekuensi, arah, taraf keadaan, bagian mana kita melalakukan sesuatu, serta hasil. Adposisi de terdapat pada peran semantik cara/alat, bahan, alasan, dan waktu. Sedangkan adposisi no terdapat pada peran semantik sifat dari kata benda yang mengikuti dan peran sintaksis penghubung tempat.

Interferensi hubungan gramatikal yang terjadi pada penggunaan adposisi bahasa Jepang dalam bahasa tulis mahasiswa sastra Jepang angkatan 2010 Universitas Brawijaya Malang adalah transfer hubungan gramatikal B1 melanggar pola hubungan gramatikal B2, tetapi maknanya masih bisa dimengerti secara tersirat. Adposisi yang termasuk dalan transfer hubungan gramatikal B1 melanggar hubungan gramatikal B2 ini adalah $n i, e$, de, $o$, dan no. Ke-empat adposisi ini rentan terjadi interferensi hubungan gramatikal B1 melanggar hubungan gramatikal B2 tapi maknanya masih dapat dimengerti. Hal ini disebabkan karena peran sintaksis maupun semantik adposisi $n i, e$, de ,o yang lebih dari satu serta ada kemiripan bunyi dengan bahasa Indonesia. Sedangkan adposisi no rentan terjadi interferensi untuk peran semantik sifat dari kata benda, karena dalam bahasa Indonesia tidak menggunakan kata sebagai penghubung noun dan noun.

Tingkat kesulitan adposisi bahasa Jepang berdasarkan interferensi yang muncul pada bahasa tulis mahasiswa sastra Jepang angkatan 2010 Universitas Brawijaya Malang adalah

Sulit ............. tougou /konvergensi (2-1)

............ dounyuu/ox

Mudah ........... taiou /transfer (1-1) 
Dari tingkat kesulitan yang didapatkan, dapat diketahui bahwa bagi mahasiswa sastra Jepang Universitas Brawijaya angkatan 2010, jika B1 lebih banyak dari pada B2, maka itu lebih menyulitkan dari pada jika pada B1 tidak ada kata yang mengekspresikan B2.Tidak cukupnya apdosisi bahasa Jepang untuk mengekspresikan preposisi bahasa Indonesia, membuat siswa memakai adposisi yang sama berulang-ulang untuk semua kalimat yang dalam Bahasa Indonesia mempunyai peran semantik yang sama.

\section{Daftar Pustaka}

Creswell.John W (2010), Research Desain, Yogyakarta, Pustaka Pelajar.

Chaer, Abdul (1998), Tata Bahasa Praktis Bahasa Indonesia, Jakarta, Gramedia

Hando, Hideaki (2005), Gendai Joshi no Bunrui, Kumamoto Kenritsu Daigaku, Bungakubu Kiyou-Dai 11 kan.

Ichikawa Yasuko ( 2006 ) ,Shokyuu Nihongo bunpou to Oshiekata no Pointo, Tokyo, 3 Network.

Ichikawa Yasuko (1997), Nihongo Goyou Reibun Shoujiten, Tokyo, Bonjisha.
Iori, Isao (2004), Chuujoukyuu o Oshieru Nihongo Bunpou Hand Book, Tokyo, 3A Network.

Kamimura,Fumiko (2002), Dai 2 Gengo toshite no Nihongo ni okeru Kaku Joshi no Shomondai, Kumamoto Daigaku Ryuugakusei Sentaa Kiyou, dai 6-go

Semata, Kumiko (2006), Dai ni Nihongo Shuutoku Kenkyuu, Tokyou, Aruku

Sugiyono, (2010), Metode Penelitian Pendidikan, Bandung, Alfabeta.

Setyawati. 2010. Analisis Kesalahan Berbahasa Indonesia. Surakarta: Yuma Pustaka.

Shibuya, Katsumi (2001, Gakushuusha no Bogo no Eikyou "Nihongo Gakushuusha no bunpou shuutoku”, Taishuukan Shoten

Tarigan, Henry G (1988), Pengajaran Analisis Kesalahan Berbahasa, Angkasa, Bandung

Tarigan, Henry G (1988), Pengajaran Pemerolehan Bahasa, Dep.Pendidikan dan Kebudayaan, Jakarta.

Weinreich, Uriel (1953), Language in Contact : Finding and Problem, Mouton: The Hague-Paris

Wirjosoedarmo Soekono 1985 Tata Bahasa Indonesia.Surabaya : Sina Wijaya. 